\title{
Scientific novel: Araucaria angustifolia branch may be converted into orthotropic trunk by grafting 1
}

\author{
Valdeci Constantino ${ }^{2}$ (D), Ivar Wendling ${ }^{3}$, Flávio Zanette ${ }^{2}$ \\ 10.1590/0034-737X202067010012
}

\begin{abstract}
Grafting technique has been presented as an alternative for Araucaria angustifolia propagation. However, vegetative rescuing mature trees and obtaining large numbers of propagules is difficult, because the use of branch grafts has not been indicated due to its plagiotropic and morphogenic characteristic, generally resulting in undesired growth of the graft. So we aimed to describe the unpublished fact occurred in four plants of A. angustifolia grafted with grafts from primary branches that resulted in conversion to trunk. Plant growth and morphology were evaluated ten years after grafting. We verified vertical growth and organization of trunk and persistent branches with defined whorls, same to plants grafted with trunk grafts. Field tests with grafted plants using grafts obtained from the four plants resulted in same development pattern, proving the permanent morphogenic change and opening new perspectives for araucaria vegetative rescue and grafting. We concluded that trunciform shoots can be obtained by A. angustifolia grafting with plagiotropic primary branches. Despite the morphological clarity of trunciform shoots on grafted plagiotropic primary branches, it has not yet been possible to identify the causes of this reversion.
\end{abstract}

Keywords: conifer; tropism; vegetative propagation; brazilian pine.

\section{INTRODUCTION}

Araucaria angustifolia is a native species of South America. With its characteristic canopy architecture, this species can reach an average of 25 meters in height and 1.5 meters in diameter. Its trunk is monopodial, cylindrical and presents rhythmic growth. Adult plants usually have regular rows of primary branches arranged in whorls (between 6 and 10 branches in each whorl) and 8 to 15 whorls. It is the dominant tree of the Mixed Ombrophilous Forest and can live 300 years or more (Zanette et al., 2017).

The economic, social and environmental importance of A. angustifolia is significant in its naturally occurring states. In the second half of the twentieth century, its timber was heavily targeted by industry leading the species to risk of extinction (Carlucci et al. 2013). Currently araucaria cutting is prohibited by law, except for plantations. The extraction of its seeds is still common, requiring investments in the establishment of orchards for the production of pine nuts. Otherwise, this activity may interfere with the natural regeneration of the species and, consequently, its maintenance.

Although still not significant, some initiatives have been observed for araucaria plantations to produce pine nuts, which may contribute to reduce the species risks of extinction. To meet this demand, research has sought highly productive genotypes, differentiated by production time, pine nut size (Zanette et al., 2017) and precocity. In parallel, alternative methods of propagation by cuttings (Wendling et al., 2017a) and by grafting (Wendling et al. 2017b), which maintain the desired characteristics of the plants, were also improved. Propagation by seeds (most common) does not allow the identification of sex before the plant enters the reproductive phase, nor does it guarantee the maintenance of the genetic quality of the selected plant.

\footnotetext{
Submitted on August 16 th, 2019 and accepted on November 10 $0^{\text {th }}, 2019$.

${ }^{1}$ Research in partnership with Embrapa Florestas.

${ }^{2}$ Universidade Federal do Paraná, Departamento de Fitotecnia e Fitossanitarismo, Curitiba, Paraná, Brazil. deco@ufpr.br; flazan@ufpr.br

3.Embrapa Florestas, Colombo, Paraná, Brazil. ivar.wendling@embrapa.br

* Corresponding author: deco@ufpr.br
} 
Despite the reduction of areas with $A$. angustifolia, it is relatively easy to identify plants with productive characteristics of interest and multiply them by established methods of vegetative propagation. However, the dimorphism of its branches and trunk, historically reported in the first grafting studies with the species (Gurgel \& Gurgel Filho, 1967; Kageyama \& Ferreira, 1975; Zobel \& Talbert, 1984), is still considered the main barrier for its propagation on a large scale.

Morphoanatomic studies have shown that terminal buds and dormant buds along the araucaria tree trunk are the only meristems normally capable of producing orthotropic (verticalized) shoot growth (Nikles, 1964). Although recent findings (identification of strigolactones, elucidation of their biosynthesis and signaling) provide relatively clear information on the molecular regulation of axillary shoot growth (Domagalska \& Leyser, 2011; Smith \& Li, 2014; Flematti et al., 2016), our understanding on axillary meristem initiation at the molecular level is still incomplete (Wang \& Jiao, 2018). In the case of araucaria, it is suggested that there are different mechanisms of internal regulation in the axilla of trunk and branch needles, as they originate plants with different crown architecture.

This paper reports araucaria grafted from plagiotropic branch propagules that resulted in plants with vertical growth and stem with morphology and trunk function. There is no mention in the literature for A. angustifolia or other Araucariacea trees regarding this, a fact that makes this discovery unprecedented and allows to make some hypotheses about such behavior.

\section{MATERIALAND METHODS}

\section{Experimental condition}

We evaluated grafted plants established in the field in an experimental area of Embrapa Forests, located in Colombo-PR (Lat. 25 19,206 'S, Long. 49 9,514' O, Alt. $928 \mathrm{~m}$ ). The region's climate is classified as temperate (Cfb according to Köppen-Geiger climate classification), with the coldest month temperature between -3 and $18^{\circ} \mathrm{C}$, humid, well-distributed rainfall throughout the year. Average annual rainfall around $1,500 \mathrm{~mm}$ without the occurrence of a dry season.

The grafts used in the grafting were obtained from shoots naturally emitted on canopy branches of 30-yearold adult trees, as can be seen in Wendling et al. (2016 Figure 1A). The grafting technique employed was by cleft graft in rootstocks of approximately 1.5 years and $80 \mathrm{~cm}$ in height produced by seeds, kept in a pot.

The grafts were finally transplanted at the field on September 2007. The plants were kept clean by periodic crowning during the first year and later by mowing. Graft growth habits, morphology and sexual reproduction initiation were evaluated.

\section{Field test to confirm grafts reversion}

The field test was composed of four plants that stood out for the change of their growth habit and morphology not previously verified in the araucaria. The main objective was to confirm the repetition of plant growth behavior after grafting, as well as the morphogenic change of the grafted branches. Propagules were removed from the apical region of the grafts sprouts, as well as from buds that appeared on the plagiotropic grafts for new grafting using the chip budding (Wendling et al., 2017b) in rootstocks produced from seeds and kept in plastic bags of $3.6 \mathrm{~L}$. Similar to what happened in the previous stage, after grafting success, the plants were definitely transplanted to the field and monitored.

This research has a descriptive character, since it presents unpublished facts and phenomena resulting from grafting with branch propagules. Understanding how these phenomena occur will be an important step to enable the vegetative rescue of mature trees from branches, as well as for the production of large-scale grafted plants.

\section{RESULTSAND DISCUSSION}

Two distinct morphogenic behaviors were observed that resulted in four plants with vertical growth and trunk morphology, in none of them was verified flower initiation. In the first one, the grafts presented clearly plagiotropic initial growth and branch morphology (Figure 1A). Over time, they began to have an orthotropic growth and trunk morphology, indicating morphogenic changes in the plant (Figure 1D).

In the second behavior, the development (induction) of vertical sprouting on the upper surface of plagiotropic graft was verified, also accompanied by morphogenic changes (Figures 2B and C).

In general, grafts from primary branches presented buds with initial inclined growth (plagiotropic) and disorganized secondary branching, identical to their place of origin (Figure 1A). At ten years of age, however, four plants were found with some growth characteristics considered unusual in araucaria grafted with this type of material, mainly because they occurred simultaneously, constituting important markers related to the change of tropism and morphogeny.

\section{Vertical growth and organization in whorls}

In Figure 1B it is possible to clearly observe the primary branch vertical growth. Although uncommon, this growth characteristic contradicts the reports of Nikles (1964) who stated in his work that the terminal bud and the dormant ones along the Araucariaceae trunk were the only meristems capable of producing buds with orthotropic growth. 

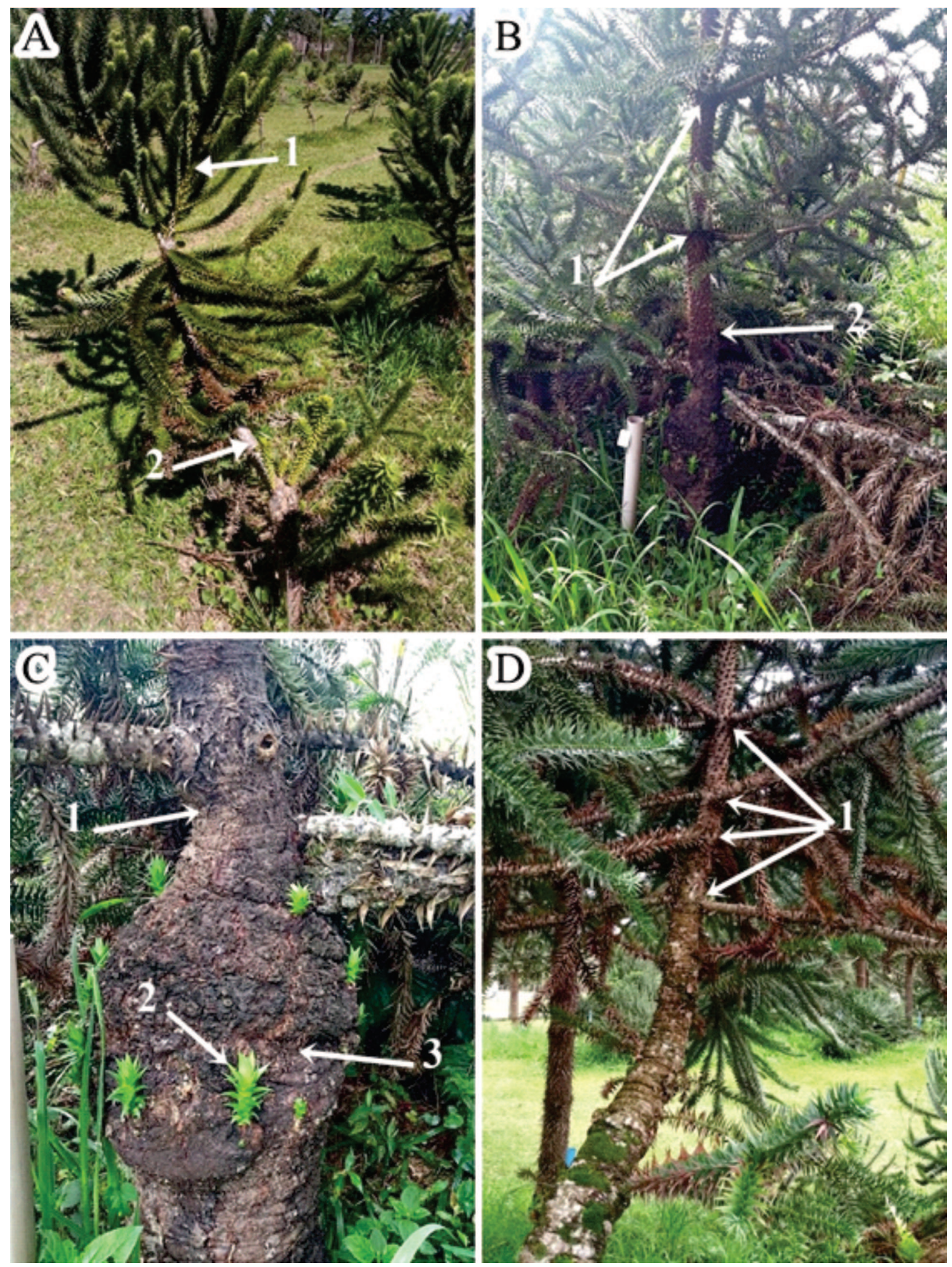

Figure 1: Different growth behaviors of A. angustifolia plants grafted from primary branches: A) Plant with disorganized secondary branching (1) and plagiotropic growth (2); B) Plant with secondary branching arranged in whorls (1) and vertical growth (2); C) Differentiation in growth rate: primary branch - determined growth (1), trunk - undetermined growth (3) and induction of orthotropic shoots in the rootstock (2); D) Plant with reversion of plagiotropism and branch-to-trunk morphology (approximately 10 years) with secondary branch organized in whorls (1). 
In Figure 1D the oldest branch (secondary branches) of the stem near the grafting region is disorganized. Plagiotropic graft tend to form a canopy architecture similar to that from which the material was obtained. In the intermediate region, however, branching began to line up in definite whorls, were it is possible to observe a fourth order of branches (Figure 2A), common in araucaria, but uncommon in plants grafted with plagiotropic branches, leading to believe in a possible morphogenic change (reversal) to the trunk.

Vertical growth of grafts from primary branches was observed in a previous survey (unpublished data) in at least $10 \%$ of the three-year-old grafted plants. However, the verticalization process was not accompanied by the organization of the secondary branches into well-defined whorls, which would characterize trunk formation, as occurred in this research. The authors attributed the type, age and position of the propagule in the canopy of the mother plant as probable determining factors for such growth behavior.

\section{Longevity and thickening of branches}

Besides the change of tropism, the plants also presented secondary branches with different growth in thickness and longevity. In Figure $2 \mathrm{~A}$ it is possible to observe that the secondary branches are thicker and of longer life when compared to branches of the plants that kept the tropism similar to the place of origin (Figure 1A), indicating physiological alterations with reflex in the plant morphogenesis. In general, the araucaria secondary branches are flexible, have anatropic growth (without preferential direction) and a limited life cycle between 5 and 7 years (Zanette et al., 2017). For a better understanding of the branches of A. angustifolia, Hackbarth et al. (2017) studied the different stems physiology of the species and found differences in the amino acids of trunk, branches and vines ("grimpas"). The result confirms the particularities of each stem and, therefore, for morphogenic change to occur (a primary branch is generated in place of a secondary branch), there must be some mechanism responsible for reprogramming gene expression and acquiring cellular competence. These issues, however, are little clarified so far (Rocha et al., 2016).

The interaction between graft and rootstock may explain, in some cases, the morphology, anatomy and physiology of grafted plants (Hartmann et al., 2011; Santarosa \& Souza, 2016). However, there are no studies on this topic in araucaria grafting with a view to morphogenic change, and it is more common to relate the interaction to the compatibility between the parts (Wendling et al., 2017b) and the crown morphology or tropism (Constantino \& Zanette, 2018).
A possible explanation for the transformations that occurred is the existence of silencing signals from genes transmissible to the graft. This concept may be the key to a new approach to the graft transformation puzzle (Mudge et al., 2009). Recent research further broadens this view in conjunction with the likely involvement of epigenetic inheritance mechanisms.

The environmental condition can induce epigenetic changes and thus reveal a hidden genetic variability. Although information about this mechanism has been growing rapidly in recent years, helping to understand various biological processes, its understanding is still a great challenge (Vieira, 2017).

Another concept also poorly understood is the "hybrid graft" in which the transfer of genetic material from the rootstock can promote graft transformation, leading to hereditary changes (Goldschmidt, 2014).

On-site observations, however, suggest a process of stress on grafts due to plant age. The araucaria trunk presents indeterminate radial growth (Figure 1C), unlike the branch that is determined (Zanette et al., 2017). Therefore, the growth rate of the rootstock can lead to incompatibility (Wendling et al., 2017b), and thus a growth stress capable of generating stress and to influence plant development.

Regarding the growth behavior of the plant in Figure $2 \mathrm{~B}$ and $\mathrm{C}$, it is possible that there has been a stress process due to local conditions (long and low growth under vegetation, competition, suffering with frequent mowing in the area in which it is found), since environmental disturbances and stress at ground level are some of the most important factors influencing the development of epicormic sprouts (Burrows, 2008; Colin et al., 2010).

Different from other species in which this type of sprouting may be the product of morphogenesis when a cambium cell transformation occurs to give rise to the new sprout (Rast et al., 1988), in the case of araucaria, sprouts originate from a set of meristematic cells in the axilla of the needles (Burrows et al., 2003). These meristems usually do not differentiate into other tissues without some stimulation (Burrows, 1990; Meier et al., 2012). Therefore, the changes observed in this work may be related to the existence of a physiological process capable of triggering a signal that reflects the morphogenic competence of cells leading to a particular and permanent development of the plant.

\section{Field test}

The growth behavior of the grafted and fieldmaintained plants was similar to that of the origin plants (plants that showed vertical growth and morphogenic change). However, the growth was vertical from the beginning of the graft sprouting and the whorls were 

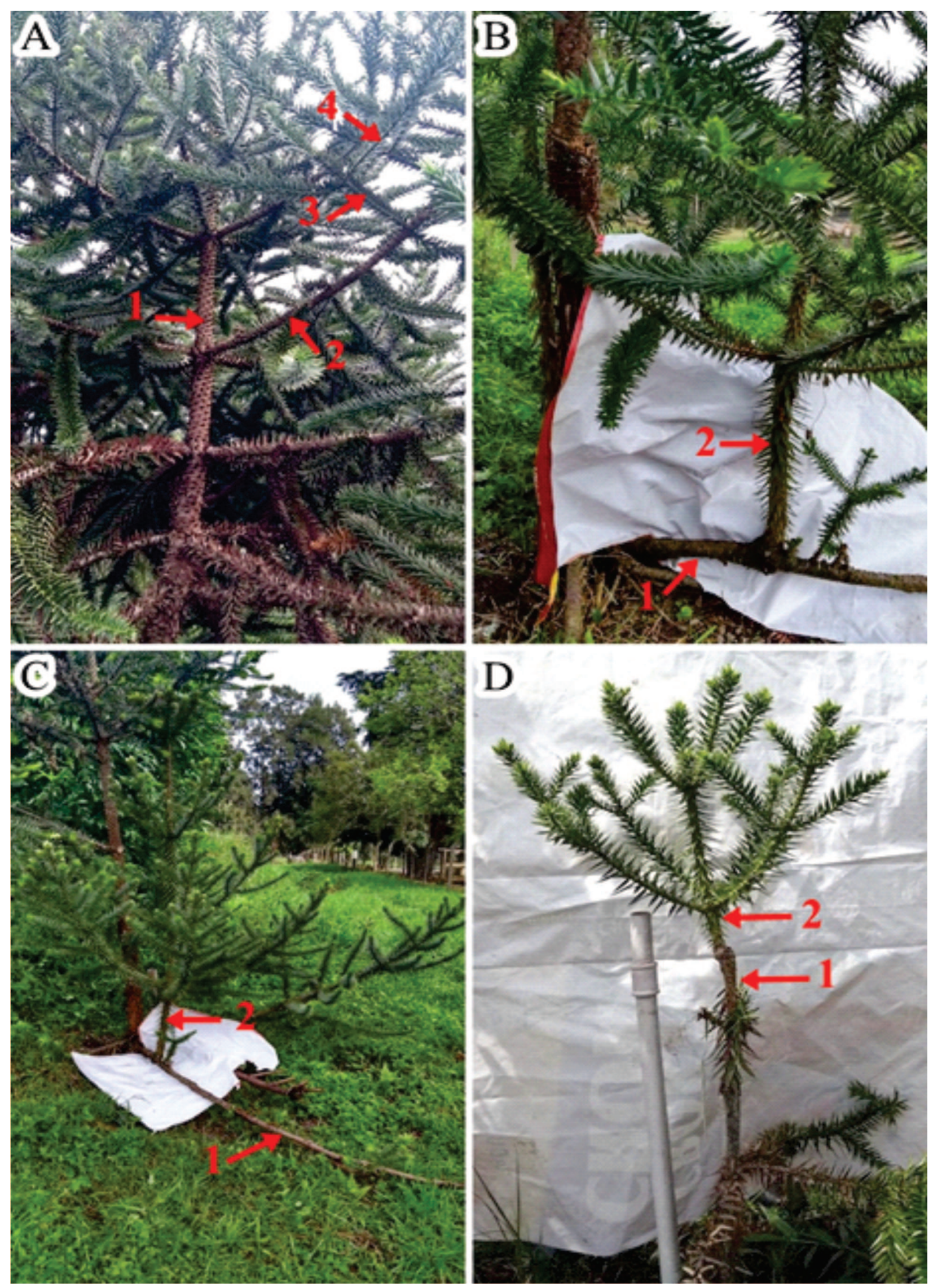

Figure 2: Thick and lignified branches arranged in definite whorls, highlighting the primary branch that was converted into main trunk (1), secondary (2), tertiary (3) and fourth order branches (4) (A); Induced orthotropic budding (2) on plagiotropic branch (1) (B and C); Field test: grafting with material obtained from plant that showed morphogenic and tropism changes (2), rootstock (1) (D). 
organized with well distributed branching (Figure 2D), reflecting an order identical to that of a plant grafted with trunk propagules of the same age. This allows us to conclude that the morphogenic changes that occurred in araucaria plants were definitive. Thus, understanding what factors are involved in this growth habit and morphology reversion from branch to trunk may open new perspectives for the vegetative rescue and grafting of araucaria branches.

\section{CONCLUSIONS}

Trunciform shoots can be obtained by A. angustifolia grafting with plagiotropic primary branches.

Despite the morphological clarity of trunciform shoots on grafted plagiotropic primary branches, it has not yet been possible to identify the causes of this reversion.

There is no conflict of interest in conducting this research and publishing the manuscript.

\section{REFERENCES}

Burrows GE (1990) The role of axillary meristems in coppice and epicormic bud initiation in Araucaria cunninghamii. International Journal of Plant Sciences, 151:293-301.

Burrows GE, Offord CA, Meagher PF \& Ashton K (2003) Axillary meristems and the development of epicormic buds in Wollemi pine (Wollemia nobilis). Annals of Botany, 92:835-844.

Burrows GE (2008) Syncarpia and Tristaniopsis (Myrtaceae) possess specialised fire-resistant epicormic structures. Australian Journal of Botany, 6:254-264.

Carlucci MB, Prieto PV, Hering RLO, Judice DM \& Monteiro NP (2013) Araucariaceae. In: Martinelli G \& Moraes MA (Eds.) Livro Vermelho da Flora do Brasil. Rio de Janeiro, Instituto de Pesquisas Jardim Botânico do Rio de Janeiro. p.185-186.

Colin F, Ducousso A \& Fontaine F (2010) Epicormics in 13yearold Quercus petraea: small effect of provenance and large influence of branches and growth unit limits. Annals of Forest Science, 67:312-323.

Constantino V \& Zanette F (2018) Grafting of trunciforms propagules in branches of Araucaria angustifolia and multiplication of selected plants. Ciência Florestal, 28:845853 .

Domagalska MA \& Leyser O (2011) Signal integration in the control of

shoot branching. Nature Reviews Molecular Cell Biology, 12:211221

Flematti GR, Scaffidi A, Waters MT \& Smith SM (2016) Stereospecificity

in strigolactone biosynthesis and perception. Planta, 243:13611373.

Goldschmidt EE (2014) Plant grafting: new mechanisms, evolucionary implications. Frontiers in Plant Science, 05:727736

Gurgel JTA \& Gurgel Filho AO (1967) Métodos de enxertia para o pinheiro brasileiro, Araucaria angustifolia (Bert) O. Ktze, visando-se a formação de pomares de sementes. Silvicultura em São Paulo, 06:153-155.
Hackbarth C, Soffiatti P, Zanette F, Floh EIS, Macedo AF \& Laureano HA (2017) Free amino acid content in trunk, branches and branchlets of Araucaria angustifolia (Araucariaceae). Journal of Forestry Research, 29:1489-1496.

Hartmann HT, Kester DE, Davies Junior FT \& Geneve RL (2011) Plant propagation: principles and practices. $8^{\text {th }}$ ed. Boston, Prentice-Hall. 915p.

Kageyama PY \& Ferreira M (1975) Propagação vegetativa por enxertia em Araucaria angustifolia (Bert.) O. Ktze. Instituto de Pesquisa e Estudos Florestais, 11:95-102.

Meier AR, Saunders MR \& Micher CH (2012) Epicormic buds in trees: a review of bud establishment, development and dormancy release. Tree Physiology, 32:565-584.

Mudge K, Janick J, Scofield S \& Goldschmidt EE (2009) A history of grafting. Horticultural Reviews, 35:437-493.

Nikles DG (1964) Araucaria cunninghamii "bark-patch" grafting in the field. Australian Forest Research, 01:45-47.

Rast ED, Beaton JA \& Sonderman DL (1988) Photographic guide to selected external defect indicators and associated internal defects in black walnut. Broomall, Northeastern Forest Experiment Station. 24p. (Research Paper, NE 617).

Rocha DI, Pinto DLP, Vieira LM, Tanaka FAO, Dornelas MC \& Otoni WC (2016) Cellular and molecular changes associated with competence acquisition during passion fruit somatic embryogenesis: ultrastructural characterization and analysis of SERK gene expression. Protoplasma, 253:595-609.

Santarosa E \& Souza PVD (2016) Alterações anatômicas do sistema vascular em porta-enxertos de videira. Pesquisa Agropecuária Brasileira, 51:320-329.

ýSmith SM \& Li J (2014) Signalling and responses to strigolactones and karrikins. Current Opinion in Plant Biology, 21:23-29.

Vieira GC (2017) Admirável mundo novo: epigenética. In: Aráujo LAL (Eds.) Evolução Biológica: da pesquisa ao ensino. Porto Alegre, Editora Fi. p.177-212.

Wang Y \& Jiao Y (2018) Axillary meristem initiation - a way to branch out. Current Opinion in Plant Biology, 41:61-66.

Wendling I, Stuepp CA \& Zuffellato-Ribas KC (2016) Araucaria angustifolia grafting techniques, environments and origin of propagation material. Revista Bosque, 37:285-293.

Wendling I, Stuepp CA \& Zanette F (2017a) Produção de mudas de araucária por estaquia e miniestaquia. In: Zanette F \& Wendling I (Eds.) Araucária: particularidades, propagação e manejo de plantios. Brasília, Embrapa. p.63-106.

Wendling I, Zanette F, Rickli-Horsti HC \& Constantino V (2017b) Produção de mudas de araucária por enxertia. In: Zanette F \& Wendling I (Eds.) Araucária: particularidades, propagação e manejo de plantios. Brasília, Embrapa. p.107-144.

Zanette F, Danner MA, Constantino V \& Wendling I (2017) Particularidades e biologia reprodutiva de Araucaria angustifolia. In: Zanette F \& Wendling I (Eds.) Araucária: particularidades, propagação e manejo de plantios. Brasília, Embrapa. p.13-39.

Zobel B \& Talbert J (1984) Applied forest tree improvement. New York, North Carolina State University. 505p.

Rev. Ceres, Viçosa, v. 67, n.1, p. 086-091, jan/feb, 2020 